\title{
Tess of the d'Urbervilles: Hardy's Nonconformist Views and Challenge of the Prevailing Social and Moral Ideology
}

\author{
Taher Badinjki \\ Dept. of English, Al-Zaytoonah University, P.O. Box 1089, Amman 11732, Jordan
}

\begin{abstract}
In Tess of the d'Urbervilles Hardy's non-conformist views are evident through the dialectic of negation which opposes institutionalized codes, and rejects the stereotypical Victorian concepts of femininity. He hovers over Tess like a stricken father, and presents her as an innocent victim, yet he has not been able to save her from her pre-destined death. His endeavours to create a Utopian society and change the cultural logos in regards to sex and gender, have been hampered by various forms of repression from editors, reviews, publishers and supporters of "the purity movement". In his attempt to avoid the trauma of rejection, he made substantial expurgations and revisions of the original text, but the tragic death at the end of the book shows that the prevailing ideology, and excessive prudishness of supporters of the league of virtue have outweighed his perceptions and defeated his liberal concepts." His frustration, bitter experience, and the unpleasant attacks waged on him and his works, were apparently influential in making him cease writing novels.
\end{abstract}

Index Terms - conventions, prudery censorship, editors, publishers

\section{INTRODUCTION}

In Tess of the d'Urbervilles [1891], (1979), Hardy presents a distressing work of genius which stands at the heart of his accomplishments. Though the story stirs one's memories of Mrs Gaskell's Ruth (1853), it is, in fact, nearer to that of Hetty Sorrel in Adam Bede (1859). The heroines of both books (Tess and Hetty) are dairymaids seduced by wealthy upper-class men. Both girls give birth to children unknown to their fathers, and both babies die, and at the end, both girls are tried for murder and sentenced to be hanged. Further similarities such as the countryside setting, the heroine's despairing journey, the relationship between the girl's "fall" and the family's removal may lead one to think that in Tess, Hardy has re-written the story of Adam Bede as he wanted it to be. Such an idea is reinforced by a philosophy diametrically opposed to George Eliot's.

While Adam Bede shows that actions carry their own consequences, and that people are victims of their deeds, Tess of the d'Urberville, as Hardy says, shows that "people are victims of miserable conditions and unfair social forces which turn deeds into a mockery of their intentions, and so people should be judged by the will rather than by the deed" (Hardy, 1979, p. 306) ${ }^{1}$.

\section{DISCUSSION}

Tess suffers from two destructive blows which greatly change her life, Alec's seduction and Angel Clare's desertion after their wedding. Her seduction, like Little Emily in David Copperfield (1850) is foreseen in the first few pages of the book. While Emily's fall springs from her coquettish ambition to rise above her class, Tess is the victim of inopportune circumstances which render her an easy prey of Alec, the upper class rake. She is put in a position where she becomes a helpless victim to Alec's seduction. The motive behind her mother's mercenary expectation that Alec would not have the heart not to love Tess, reveals the wanton thinking of the mother who expects, and seems prepared to accept an affair between her daughter and the libertine young man. When Tess comes back home pregnant, her mother blames her for not inducing Alec to marry her. Any "woman would have done it but you, after that!" (Tess, p. 69) It is precisely this moral difference in Tess that allows her to stay pure. Indeed, "Hardy's effort to singularise his heroine has led him to differentiate her voice from stereotypes of the feminine" (Higonnet, 2014, p. 17). Tess's attitude is meant to redefine the accepted social and moral code. Her resistance to play her trump card further serves to set her apart from the norm.

Hardy is more embittered against society and its inflexible moral code. He is more outspoken than he has been in his previous novels, and far more severe in his denunciation of prudish social attitudes which have one law for all circumstances which accept no deviation from its morally righteous ideals. In his Preface to the Fifth Edition, he has

\footnotetext{
${ }^{1}$ Hardy, Thomas (1979). Tess, p. 306. Further references to this edition will appear in the text as Tess. 
written this novel being one "wherein the great campaign of the heroine begins after an event in her experience which has usually been treated as fatal to her part of the protagonist" (Preface to the Fifth Edition, 1892, p1).

The next tragic incident in Tess's life is the rejection of Angel Clare, She pardons his moral lapse with a woman in London, but he negatively fails to recognize the parallel and retorts that forgiveness "does not apply to the case! You were one person; now you are another". The woman "I have been loving is not you, another woman in your shape"(Tess, 1979, p. 191). The crudities of Clare's hypocrisy and conventional standards of judgement, not only deprive Tess of forgiveness, but drive her from him towards tragedy. Through Angel Clare's attitude, Hardy is able to wage his attack on society's hypocrisy and cruelty and shows the gap in the Victorian attitude towards women and sex which popularizes the cult of virginity. Both Alec and Angel shatter Tess's happiness and cripple her life. For Alec, Tess is "no more than an insignificant creature to toy with and dismiss" (Tess, p. 130). He sees her as something that belongs to him, as D.H. Lawrence writes, she is "the embodiment of his desire" (1936, p. 483). Angel's condemnation and consequent desertion come as a complement to Alec's selfish cruelty. While Alec attacks her physically, Angel breaks her spiritually and makes her a miserable sufferer. The comparison, in phase five of the book headed by the suggestive title "The Woman Pays", between Tess, and the wounded and dying game-birds, is strikingly symbolic. In their different ways, both Tess and the birds are helpless victims of society-Tess of hypocritical moral standards which crush her and drive her to her tragic death, the birds of the cruelty of man's caprices which allow them to be shot at for fun.

When Alec offers to make her his demimonde, Tess angrily responds "I cannot! I should be your creature to go on doing that, and I won't" ( Tess, 1979, p. 60). Her refusal of his offer is meant to prove to the reader that though her physical body may have been compromised, her moral sense has not. According to traditional standards, she has lost her virginity, but she will not allow herself to be a whore. She refuses to become the chattel or slave of her seducer" (Jeke, 1986, p. 165). She stands as a pure woman with a warm heart, and with a fortitude in the face of adversity as "the finest woman in all the Wessex Novels" (Weber, 1940, p. 132). Even the "crime" of "deception" with Clare is not of her making, but the pure result of an unfortunate incident of misplacement. In Brazil, Angel Clare comes to judge Tess - as all humans should be judged — not by achievement, but by tendency. When he returns to England seeking her

"He had undergone some strange experience in his absence; he had seen the virtual Faustina in the literal Cornelia, a spiritual Lucretia in a corporeal Phryne; he had thought of the woman taken and set in the midst as one deserving to be stoned, and of the wife of Uriah being made a queen; and he had asked himself why he had not judged Tess constructively rather than biographically, by the will rather than by the deeds" (Tess, 1979, pp. 305-6).

These are the standards that Hardy is seeking to judge Tess by, and in putting his case, he avails himself of every opportunity to show the cruel injustice of the existing conventions and Standards of judgement.

The adding of "A Pure Woman" can be seen as an open challenge. He stresses that Tess is "pure", purer than many so-called unsullied virgins, though she gives birth to a child out of wedlock. She is still spiritually chaste because she never intended to do wrong. In his letter to Roden Noel, dated May 17, 1892, he wrote "the heroine was essentially pure - purer than many a so-called unsullied virgin: therefore I called her so" (Purdy and Millgate, 1978, p. 267). In challenging the prevalent logos of femininity and purity, Hardy makes a distinction between the act and intention, and argues that since we live in a "blighted" world, we must not be accountable for our acts and their consequences, but only for our moral inclination. Therefore, from the events preceding her seduction, it becomes clear that Tess does not, in any way, encourage Alec's soliciting and shows chaste independence of mind and body and her rape is related to Alec's lack of moral restraints. Commenting on this, Hardy writes "an immeasurable social chasm was to divide our heroine's personality thereafter from that previous self of hers who stepped from her door to try her fortune at the Tantridge poultry farm" (Tess, 1979, p. 58). The suggestion is that Tess, prior to her encounter with Alec, has been her own person. After his liberties with her, her budding sense of self has been utterly stripped from her and she calls her illegitimate child "Sorrow" to reflect its infamous and inglorious birth.

Many people found the sub-title of the book "A Pure Woman Faithfully Presented" challenging. In his Explanatory Note to the First Edition (1891), expecting the protests, he wrote:

"I will just add that the story is sent out in all sincerity of purpose, as an attempt to give artistic form to a true sequence of things; and in respect of the book's opinions and sentiments, I would ask any too genteel reader who cannot endure to have said what everybody nowadays thinks and feels, to remember a well-worn sentence of St. Jerome's: If an offence come out of the truth, better is it that the offence come than that the truth be concealed" (p.1).

His explanation does not seem to have convinced all his opponents, and the controversy continued.. In his attempt to find a publisher for the book he encountered roadblocks. In 1889 he submitted the book to Tillotson \& Sons publishers under the name "Too Late, Beloved", but "they refused to publish it. They liked neither "the narrative content nor the moral emphasis" (Millgate, 1982, p. 300). It was also rejected by Murray's Magazine and Macmillan's Magazine. After these setbacks, he changed the title to Tess of the d'Urbervilles and was compelled to make substantial revisions and expurgations. The book was finally accepted by The Graphic whose editors insisted that further significant changes be made. 
Hardy was deeply sensitive to the opinions of the British public and their criticism, and worried about finding a publisher who would accept the manuscript without the risk of asking for further editing and changes. He had no choice but to acquiesce to the prevailing conventions and the demands of prudish guardians of public morality, yet critics harshly attacked it. According to Millgate, (1982), "The Spectator attacked the book's morality, the New Review, and the Quarterly Review declared that Hardy "told a coarse and disagreeable story in a coarse and disagreeable manner" (p. 307). In response to "the demands of the editor of the Graphic" the scene in which "Tess is raped by Alec in the Chase forest and its consequences, along with the christening and the death of the child, were simply removed" (Goater, 2015, Para 7). In his essay "Candour in English Fiction", which he wrote in the middle of the controversy surrounding Tess, he attacked prude editors and publishers who "do not foster the growth of the novel which reflects and reveals life" (Orel, 1966, p. 127).

Tess's killing of Alec at the end of the book seems to be motivated by more than one reason. Alec is the villain of an unjust world. Like Carker in Dombey and Son, he gets fat on the sins and exploitation of others, and has behind him a series of crimes and manipulation which obviously have done him no appreciable harm. He is spared the world's reproaches and punishment, and it is through Tess that he pays his retribution for blundering selfishly across the lives of those beneath him.

The other and more direct reason for the murder is that Alec emerges again as an impediment to her union with Angel Clare. By killing him, she is able to go back to Clare, who has returned to her. After the murder, she tells Clare: "He has come between us and ruined us, and now he can never do it any more" (Tess, 1979, p. 318). After the murder, Tess enjoys a short and blissful honeymoon with Clare away from society's equivocal standards of judgement and random classification; but the same unjust laws which condemned her before and forced her to take justice into her own hands, sentence her to death for the very crime they pushed her to., Tess is deprived of human pardoning. There is no one to stand by her or help her in her adversity. She attracts compassionate understanding from cold, lifeless, and inanimate things only:

"The wall felt warm to her back and shoulders, and she found that immediately within the gable was the cottage fireplace, the heat of which came through the bricks. She warmed her hands upon them, and also put her cheek-red and moist with the drizzle-against their comforting surface. The wall seemed to be the only friend she had". (Tess, 1979, p. 235)

She walks to the scaffold, with no hope of a saviour to snatch her from the gallows, and despairingly says "I am ready" (Tess, 1979, p. 328). The readers do not witness the execution, nor do they know any details of what goes on inside the building. The black flag that is raised on the prison tower is the only indication of the application of "justice" followed by the omniscient narrator's ambiguous, elliptical language "Justice was done, and the President of the Immortals (in Aeschylean phrase) had ended his sport with Tess" (Tess, p. 330). Neither he, nor the reader believes Tess's absurd fate to be "just" in any real sense. The use of the dialectics of negation in which he says one thing and means the opposite, and the cynical context in which "justice" is mentioned between quotation marks, emphasizes the sarcastic and negative meaning of the term which reflects the contrast between the "just" appearance and the "unjust" reality of the case. The sarcasm with which he comments on her hanging summarizes his pity, his frustration and his anger. He "does not describe Tess's death in detail". Instead, he tells "how onlookers watch the cornice of a tower as a tall staff is fixed to it. A few minutes after the hour had struck something moved slowly up the staff, and extended itself upon the breeze. It was a black flag. 'Justice' was done" (Tess, p. 330). The hanging scene is reported, but not portrayed in details. Many studies commented on the sad ending, but few, if any, gave a satisfactory reason for reporting the scene and not describing it. I tend to believe that there is more than one reason for that. The first reason is Hardy's memory of the gruesome spectacle of the hanging of Marth Brown, who was convicted of murdering her violent husband. The hanging took place on a rainy day and had a huge impact on his life and work. Describing Martha's body on the scaffold he later wrote "I remember what a fine figure she showed against the sky as she hung in the misty rain, and how the tight black silk set off her shape as she wheeled half-round and back" (Millgate, 1982, p. 62-63). In a letter to a friend (Lady Hester Pinney), expressing the shame he still felt at having witnessed the ghastly spectacle, (Quoted in Bilyeau, The Murder That Inspired Hardy's). A recent report in The Guardian mentions that "the excavators found the bones at Dorchester prison in Dorset. The remains, including a skull, were uncovered at the prison" (Morris, 2016, par. 3). The discovery has caused huge excitement among Hardy "enthusiasts, who believe the bones may be those of Brown, whose hanging inspired Tess's unpleasant end". In handwritten notes of her conversations with Hardy, "Lady Pinney describes how he talked of Martha and Tess. "His sympathy for these unhappy women was wonderful," she wrote (Morris, 2016, para. 11). He hated the grisly hanging scene and he did not want to portray it in his novel.

The second reason for symbolically reporting "the hanging scene" and not describing it in detail, is his anger and frustration at the end to which Tess comes and if Tess has to pay, he does not portray her hung on the gallows like convicts and criminals; that is why the hanging is reported and not physically described. To him, Tess is a victim of inopportune circumstances. His compassion for her is evident throughout the book, yet he is not able to save her from her imminent death.

The harsh and breathtaking injustice to which Tess is subjected, not only arouses the reader's pity, but rage and indignation against society's prudish attitudes and rigid standards of judgement. Hardy's compassion for her is evident 
throughout the book. He "hovers and watches over [her], like a stricken father" (Howe, 1968, p. 131), and the epigraph with which he prefaces the story "poor wounded name! My bosom Shall lodge thee", more than the subtitle, sets the sympathetic tone of the book. These lines are taken from Shakespeare's play Two Gentlemen of Verona (I, ii), in which Julia continues "till thy wound be thoroughly healed". The epigraph refers to Tess as the wounded name. The rest of the line is left out, but the suggestion here is the "wound" could, perhaps, be "healed" is still there, though it's not directly mentioned.

The book sold more rapidly than any novel Hardy ever wrote, and in a six-month period, it ran into its fourth edition. "Everyone was talking about Tess of the d'Urbervilles. Everyone wanted to read it" (Weber, 1940, p. 130), yet despite the success that it scored, its publication occasioned a storm of controversy which made it the topic of heated discussions in the literary circles of the day. The two most important points around which the controversy raged were: the subtitle "A Pure Woman Faithfully Presented", and the sarcastic sentence "justice was done, and the President of the Immortals, in Aeschylean phrase, had ended his sport with Tess" (Tess, 1979, pp. 330).

Critics were divided into two clusters. On the one hand, there were the guardians of public morality and supporters of came to be known as the "purity movement", which became more and more vocal at various levels of society at the end of the century, who attacked Hardy for telling "an unpleasant story in a very unpleasant way" (Lerner \& Holmstrom, 1968, p. 61). On the other hand, there were those who were angry at the tragic conclusion of the story which, they argued, was forced on the plot by Hardy's "pessimistic" and "fatalistic" views. Their objection, similar to that raised against Adam Bede and Ruth, was that Tess's death is incongruous with the sympathetic tone of the book and that the author who aroused their sympathies for his heroine should have arranged matters in a way which would fulfil his readers' desire for a happy ending (Lang, 1892, p. 248). One of the prominent figures among this group was George Moore, who called Hardy "one of George Eliot's miscarriages" (Dick, 1972, p. 211) and who tried in Esther Waters, published three years later (1894), to show how he could treat the fallen woman's theme in a superior manner. Hardy "shifts the Victorian view of good and evil, and tries to show the hypocrisy and superficiality of such beliefs". According to Stout, "at every opportunity, Hardy turns conventional vice to virtue. In the process, he challenges the idea of the double standard, both offering a vindication of Tess's motives" and, "like Hawthorne in [The Scarlet Letter], exposing the injustice of the resulting penalties" (1987, p. 243). His attack on critics, condemnation of society's intolerance and his endeavour to alter the cultural logos in regards to sex and gender, have not been unanimously accepted. The novel was rejected at the last minute before publication. Conservative critics, publishers, editors and readers were not prepared, and would not accept a work which transgressed social conventions. Hardy had to acquiesce to the demands of journals editors, re-write some scenes and make changes against his will and satisfaction to please the taste of editors and sponsors. After the publication of the book, and the fierce criticism that followed, Hardy was disillusioned and angry that critics could not see past social conventions. After a similar unhappy experience in publishing his next novel Jude the Obscure, he ceased writing novels and focused his efforts on writing poetry.

\section{CONCLUSION}

In creating his non-conformist heroine and presenting her as a pure woman, Hardy tries to open the eyes of his public to observe the harsh injustice of society and the unjust restriction imposed on femininity and its subsequent aftermath. He makes his voice heard and his outspoken attitudes are tactile in the novel where he bravely challenges the institutionalized moral and social codes. Tess's tragic death at the end of the book, and his genuine commiserations successfully show that the prevailing ideology and the perceptions of the time have outweighed his thoughts and perceptions. However, Tess of the d'Urbervilles together with Jude the Obscure, his next book, show his substantial contribution as a Victorian male novelist who tried hard to oppose and challenge the ideologies circulating at the time. After the work was rejected by his publisher, Hardy made substantial expurgations. He spent a great deal of time revising the novel and several passages were removed or modified in order to avoid the trauma of rejection. He faced a similar unhappy experience in publishing his next novel Jude the Obscure in 1894, and that was understandably the reason why he decided to cease writing novels.

\section{REFERENCES}

[1] Bilyeau, N. (2019, 25 Oct). The murder that inspired Hardy's 'Tess of the d'Urbervilles'. The Telegraph. Retrieved from https://medium.com/@tudorscribe/the-murder-that-inspired-hardys-tess-of-the-d-urbervilles-f132e6f77845

[2] Dick, S. (1972). (ed). George Moore, confessions of a young man. London: McGill-Queen's University Press. Floger Shakespeare Library.

[3] Goater, Thierry. (2015). Repression and expression of sexuality in Thomas Hardy's Tess of the d'Urbervilles: The paradox and virtue of censorship. Revue LISA E-journal, xiii-n1

[4] Hardy, Thomas. [1891], (1979). Tess of the d' Urbervilles. New York: Norton. All further page references will be cited in the text.

[5] Higonnet, Margaret R. (2014 15 May). Sexuality and desire in Tess of the D’Urbervilles, Discovering literature: Romantics \& Victorians. Retrieved from <https://www.bl.uk/romantics-and-victorians/articles/sexuality-and-desire-in-tess-of-thedurbervilles. 
[6] Higonnet, Margaret R. (1993). (ed). A woman's story: Tess and the problem of voice. The Sense of Sex: Feminist perspectives on Hardy. Urbana: U of Illinois Press.

[7] Howe, Irving. (1968). Thomas Hardy. London: Weidenfeld and Nicholson.

[8] Jekel, Pamela L. (1986). Thomas Hardy's heroines: A chorus of priorities. Troy, New York: Whitson.

[9] LaCroix, Alison, L. \& Martha Nussbaum (eds). (2013). Rape, seduction, purity, and shame”. Subversion and sympathy: Gender, law, and the British novel. Oxford: OUP.

[10] Lang, A. (1892). Literature and drama, New Review, vol. 6, 247-9.

[11] Lawrence, D.H. (1936). A study of Thomas Hardy, Phoenix, London: Hienmann.

[12] Lerner, L. \& John Holmstrom. (Eds). ((1968). Thomas hardy and his readers, London: Bodley Head.

[13] Millgate, Michael. (1982). Thomas Hardy: A biography. New York: Random House..

[14] Morris, Steven. (2016, 16 Feb). Bones found at prison may belong to real-life Tess of The d'Urbervilles",The Guardian, International Edition. Retrieved from https://www.theguardian.com/books/2016/feb/19/thomas-hardy-tess-of-the-durbervillesbones-found-at-prison

[15] Orel, Harold. (ed). (1966). Thomas hardy's personal writings: Prefaces, literary opinions, reminiscences. Kansas: University of Kansas Press.

[16] Paris, Bernard, J. (1969-1970). A confusion of many standards: Conflicting value systems in Tess of the d'Urbervilles". Nineteenth-Century Fiction, vol. 24, 57-97.

[17] Purdy, R. L. \& M. Millgate. (1978). The collected letters of Thomas Hardy, Oxford: Oxford: Clarendon Press.

[18] Shakespeare, W. (1594). The two gentlemen of Verona, editor, Mowat, Barbara A, New York: Simon \& Schuster.

[19] Stout, Janis P. (1987). The fallen woman and the conflicted author: Hawthorne and Hardy, American Transcendental Quarterly, vol. 3, 233-46.

[20] Van Ghent, D. (1961). The English novel: Form and function, New York: Harper \& Brothers.

[21] Weber. Carl J. (1940). Hardy of Wessex: His life and literary career, New York: Columbia University Press.

Taher Badinjki, has a Master of Letters (MLitt) from Edinburgh University and PhD from Glasgow University (UK), and is presently a freelance professor of English. He is former Professor of English at the Dept. of English Literature at Al Zaytoonah University, Amman, Jordan, and the Dean of the Faculty of Arts and Humanities at the University of Aleppo in Syria, and Ittihad University in RAK, United Arab Emirates. He has published research papers and a number of books on English and American Literature, Translation, and Arabicization in Kuwait, Syria, USA, UAE and Jordan. He has been working in the field of English Literature, translation and Arabicization for over 25 years. He has taught English Language and Literature at undergraduate and postgraduate levels. He has international work experience in Syria, USA, UAE and Jordan. 